\title{
Antiprotozoal and Antibacterial Activity of Ravenelin, a Xanthone Isolated from the Endophytic Fungus Exserohilum rostratum
}

\author{
Jeferson Rodrigo Souza Pina ${ }^{1,+}{ }^{\mathbb{D}}$, João Victor Silva-Silva ${ }^{2,+}$, Josiwander Miranda Carvalho ${ }^{1}$, \\ Heriberto Rodrigues Bitencourt ${ }^{1}$, Luciano Almeida Watanabe ${ }^{1}$, Juan Matheus Pereira Fernandes ${ }^{2}$ (D), \\ Guilherme Eduardo de Souza ${ }^{3}$ (D) Anna Caroline Campos Aguiar ${ }^{3}$, Rafael Victorio Carvalho Guido ${ }^{3}$ (D), \\ Fernando Almeida-Souza ${ }^{2,4}$ (D), Kátia da Silva Calabrese ${ }^{2}$ D , Patrícia Santana Barbosa Marinho ${ }^{1}$ (D) \\ and Andrey Moacir do Rosario Marinho ${ }^{1, *}$
}

Citation: Pina, J.R.S.; Silva-Silva, J.V.; Carvalho, J.M.; Bitencourt, H.R.; Watanabe, L.A.; Fernandes, J.M.P.; Souza, G.E.d.; Aguiar, A.C.C.; Guido, R.V.C.; Almeida-Souza, F.; et al. Antiprotozoal and Antibacterial Activity of Ravenelin, a Xanthone Isolated from the Endophytic Fungus Exserohilum rostratum. Molecules 2021, 26, 3339. https://doi.org/10.3390/ molecules26113339

Academic Editor: Francisco Leon

Received: 8 April 2021

Accepted: 11 May 2021

Published: 2 June 2021

Publisher's Note: MDPI stays neutral with regard to jurisdictional claims in published maps and institutional affiliations.

Copyright: (C) 2021 by the authors Licensee MDPI, Basel, Switzerland. This article is an open access article distributed under the terms and conditions of the Creative Commons Attribution (CC BY) license (https:/ / creativecommons.org/licenses/by/ $4.0 /)$.
1 Post-Graduate Program in Chemistry, Federal University of Pará, 66075-110 Belém, Brazil; konanquim@gmail.com (J.R.S.P.); mcwander@hotmail.com (J.M.C.); heriberto.ufpa@gmail.com (H.R.B.); lucianowat@yahoo.com.br (L.A.W.); pat@ufpa.br (P.S.B.M.)

2 Laboratory of Immunomodulation and Protozoology, Oswaldo Cruz Institute, Oswaldo Cruz Foundation, 21040-360 Rio de Janeiro, Brazil; jvssilva89@gmail.com (J.V.S.-S.); juanfernandes222@gmail.com (J.M.P.F.); fernandoalsouza@gmail.com (F.A.-S.); kscalabrese@gmail.com (K.d.S.C.)

3 São Carlos Institute of Physics, University of São Paulo, São Carlos, 13566-590 São Paulo, Brazil; guilherme.eduardo.souza@usp.br (G.E.d.S.); carolcaguiar@yahoo.com.br (A.C.C.A.); rvcguido@ifsc.usp.br (R.V.C.G.)

4 Post-Graduate Program Animal Sciences, State University of Maranhão, 65055-310 São Luís, Brazil

* Correspondence: andrey@ufpa.br; Tel.: +55-91-3201-8050

+ These authors contributed equally to this work.

\begin{abstract}
The natural compound ravenelin was isolated from the biomass extracts of Exserohilum rostratum fungus, and its antimicrobial, antiplasmodial, and trypanocidal activities were evaluated. Ravenelin was isolated by column chromatography and HPLC and identified by NMR and MS. The susceptibility of Gram-positive and Gram-negative bacteria strains to ravenelin was determined by microbroth dilution assay. Cytotoxicity was evaluated in hepatocarcinoma cells (HepG2) and BALB/c peritoneal macrophages by using MTT. SYBR Green I-based assay was used in the asexual stages of Plasmodium falciparum. Trypanocidal activity was tested against the epimastigote and intracellular amastigote forms of Trypanosoma cruzi. Ravenelin was active against Gram-positive bacteria strains, with emphasis on Bacillus subtilis (MIC value of $7.5 \mu \mathrm{M}$ ). Ravenelin's antiparasitic activities were assessed against both the epimastigote ( $\mathrm{IC}_{50}$ value of $\left.5 \pm 1 \mu \mathrm{M}\right)$ and the intracellular amastigote forms of $T$. cruzi ( $\mathrm{IC}_{50}$ value of $9 \pm 2 \mu \mathrm{M}$ ), as well as against $P$. falciparum ( $\mathrm{IC}_{50}$ value of $3.4 \pm 0.4 \mu \mathrm{M})$. Ravenelin showed low cytotoxic effects on both HepG2 $\left(\mathrm{CC}_{50}>50 \mu \mathrm{M}\right)$ and peritoneal macrophage $\left(\mathrm{CC}_{50}=185 \pm 1 \mu \mathrm{M}\right)$ cells with attractive selectivity for the parasites (SI values $>15$ ). These findings indicate that ravenelin is a natural compound with both antibacterial and antiparasitic activities, and considerable selectivity indexes. Therefore, ravenelin is an attractive candidate for hit-to-lead development.
\end{abstract}

Keywords: antimicrobial; antiprotozoan; polyketides; fungi; xanthone

\section{Introduction}

Secondary metabolites produced by microorganisms, including fungi and bacteria, have shown useful applications in different areas of human life development [1]. Penicillin is the most well-known example of a secondary metabolite produced by a microorganism that has been used against microbial diseases [2].

Fungi produce diverse classes of bioactive compounds [3,4]. Several studies have demonstrated the potential of endophytic fungi as producers of bioactive compounds. 
The natural products of endophytic fungi show a variety of both biological activities and chemical classes, including alkaloids, steroids, terpenoids, flavonoids, glycosides, xanthones, isocoumarins, quinones, phenylpropanoids, lignans, aliphatic metabolites, and lactones, among others [5].

The increasing number of resistant pathogens (bacteria and fungi) to the antimicrobials available [6] and the loss of effectiveness to antiprotozoal treatment [7] have motivated the investigation of bioactive compounds from natural sources. In this sense, secondary metabolites isolated from endophytic fungi may play a role against microbial and parasite resistance [8]. For instance, isocoumarins analogs have been obtained from cultures of E. rostratum isolated as endophytic fungi of Stemona sp., and had their biological activity assessed against a resistant strain of $P$. falciparum (K1, multidrug-resistant strain). The most potent compound of the series showed inhibitory activity in the submicromolar range $\left(\mathrm{IC}_{50}\right.$ of $0.68 \mu \mathrm{M})$ [9].

Xanthones are natural products isolated from plants and microorganisms, including endophytic fungi $[10,11]$. Despite its simple chemical structure, the investigations around the xanthone core have generated a large number of xanthone analogs [12]. These analogs have shown a variety of biological activities [13], including antidepressant and anxiolytic [14], antitubercular [15], antimicrobial [16], anticancer [17], antiviral [18], antioxidant [19], anti-inflammatory [20], and antiparasitic [21].

In this work, the fungus E. rostratum was isolated from Phanera splendens (Kunth) Vaz (Leguminosae), an endemic medicinal plant of the Amazon region known as "Tortoise Ladder" and used in folk medicine against infectious, inflammatory, and diabetes processes [22], was studied. There are few studies in the literature on the chemistry of the genus Exserohilum. A previous chemical study on E. rostratum reported the isolation of polyketides with lactone skeleton of tri-substituted $\alpha$-pyrone with moderate antimicrobial activity [23]. Then, xanthone ravenelin was obtained by us, and the aim of this work was to study the therapeutic potential of ravenelin as antimalarial, antichagasic or antileishmanial. Therefore, to the best of our knowledge, this is the first report about its antiprotozoal profile.

\section{Results}

\subsection{Isolation and Characterization of Ravenelin}

The compound ravenelin 1 was isolated from the fraction A3 of the ethyl acetate extract from E. rostratum by a preparative high-performance liquid chromatography with a photodiode array detector (HPLC-PAD) (Figure 1). The electrospray ionization mass spectrum (ESIMS) (-) of compound 1 showed $m / z 257.2[\mathrm{M}-\mathrm{H}]^{-}$, which, combined with the NMR data, allowed us to propose the molecular formula $\mathrm{C}_{14} \mathrm{H}_{10} \mathrm{O}_{5}$. The structure of the isolated compound was determined by one- (1D) and two-dimensional (2D) NMR, FTIR, and MS data (Supplementary Material).

\subsection{Antibacterial Activity of Ravenelin}

The antibacterial activities of ravenelin were evaluated against Gram-positive and Gram-negative bacteria (Table 1). The results indicated that ravenelin did not show inhibitory activity against Gram-negative strains (MIC > $1000 \mu \mathrm{M}$ ), but showed inhibition against Staphylococcus aureus (MIC value of $484 \mu \mathrm{M}$ or $125 \mu \mathrm{g} / \mathrm{mL}$ ) and Bacillus subtilis (MIC value of $7.5 \mu \mathrm{M}$ or $1.95 \mu \mathrm{g} / \mathrm{mL}$ ). Amoxicillin and terramycin were used as positive controls (Table 1). 
Table 1. Minimum inhibitory concentration (MIC) of ravenelin for Gram-negative and Grampositive bacteria.

\begin{tabular}{cccccc}
\hline \multirow{2}{*}{ Compound } & \multicolumn{5}{c}{ MIC $(\mu \mathrm{M})$} \\
\cline { 2 - 6 } & B. subtilis & S. aureus & E. coli & P. aeruginosa & S. typhimurium \\
\cline { 2 - 6 } & 7.5 & 484 & $>1000$ & $>1000$ & $>1000$ \\
Ravenelin & 1.3 & 21.4 & 21.4 & 21.4 & 21.4 \\
Amoxicillin & 16.3 & 16.3 & 16.3 & 16.3 & 16.3 \\
Terramycin & &
\end{tabular}

MIC: minimum inhibitory concentration. Bacillus subtilis (ATCC 6633), Staphylococcus aureus (ATCC 25923), Escherichia coli (ATCC 25922), Pseudomonas aeruginosa (ATCC 27853), and Salmonella typhimurium (ATCC 14028).

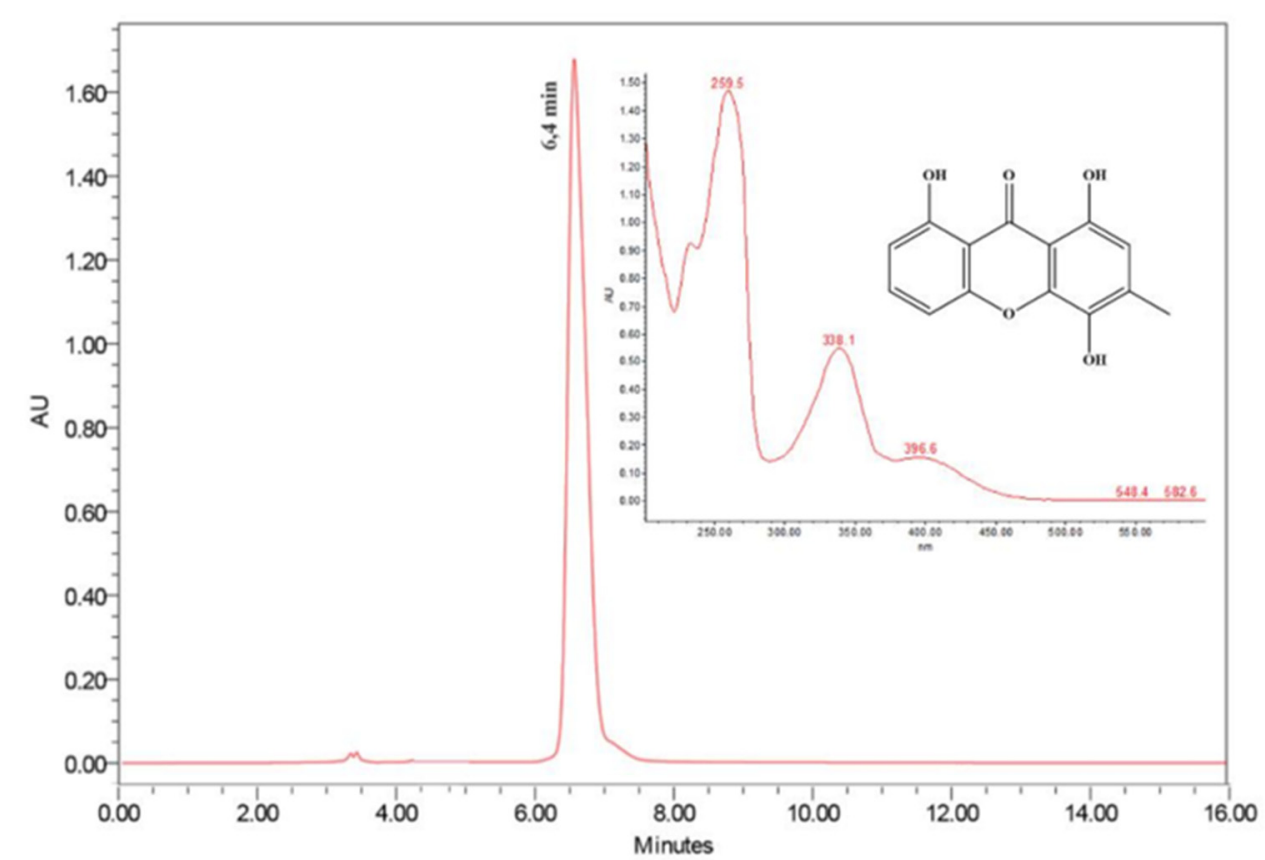

Figure 1. Preparative HPLC-PAD chromatogram at $254 \mathrm{~nm}$ of fraction A3 obtained of ethyl acetate from E. rostratum. UV-Vis spectrum of ravenelin $\left(t_{R}=6.4 \mathrm{~min}\right)$. Sunfire ${ }^{\mathrm{TM}}$ prep C18 OBD column $\left(5 \mu \mathrm{m}, 19 \mathrm{~mm} \times 150 \mathrm{~mm}\right.$ ), $500 \mu \mathrm{L}$ of injected volume of the sample, gradient elution $\mathrm{H}_{2} \mathrm{O} / \mathrm{MeOH}$ (90-100\%) for $16 \mathrm{~min}$, flow $9.0 \mathrm{~mL} / \mathrm{min}$, PAD range $210-600 \mathrm{~nm}$.

\subsection{Antiplasmodial and Anti-Trypanosoma Effect of Ravenelin}

Ravenelin was tested in vitro against cultures of $P$. falciparum 3D7, a chloroquinesensitive strain, and T. cruzi (epimastigote and intracellular amastigote forms) (Table 2). Artesunate and benznidazole were used as positive controls for inhibition against $P$. falciparum and T. cruzi, respectively. The compound showed antiplasmodial $\left(\mathrm{IC}_{50}=3.4 \mu \mathrm{M}\right)$ and trypanocidal activities $\left(\mathrm{IC}_{50}{ }^{\mathrm{Epi}}=5 \mu \mathrm{M}\right.$ and $\left.\mathrm{IC}_{50}{ }^{\text {ama }}=9 \mu \mathrm{M}\right)$ in the low micromolar range.

Table 2. Antiprotozoal activities of ravenelin.

\begin{tabular}{cccc}
\hline & P. falciparum & \multicolumn{2}{c}{ T. cruzi } \\
\cline { 2 - 4 } Compounds & \multirow{2}{*}{ IC $_{\mathbf{5 0}}(\boldsymbol{\mu M})$} & Epimastigote & Intracellular Amastigote \\
\cline { 2 - 4 } & & IC $_{\mathbf{5 0}}(\boldsymbol{\mu M})$ & IC $_{\mathbf{5 0}}(\boldsymbol{\mu M})$ \\
\hline Ravenelin & $3.4 \pm 0.4$ & $5 \pm 1$ & $9 \pm 2$ \\
Artesunate & $0.0085 \pm 0.0008$ & $\mathrm{NA}$ & $\mathrm{NA}$ \\
Benznidazole & $\mathrm{NA}$ & $22 \pm 1$ & $2 \pm 1$ \\
\hline
\end{tabular}

Data represents mean \pm SD of at least two experiments. $\mathrm{IC}_{50}$ : inhibitory concentration for $50 \%$ of parasite inhibition. NA, not applicable. 
The analysis of the infection indicated that ravenelin determined a statistically significant reduction in the number of amastigotes per 100 cells $(p=0.0226$; Figure 2a), the percentage of infected cells $(p=0.0286$; Figure $2 b)$, and the mean of amastigotes per infected cell ( $p=0.0119$; Figure $2 c)$, but only at the greatest concentration tested $(3.87 \mu \mathrm{M}$ or $1 \mu \mathrm{g} / \mathrm{mL}$ ). By contrast, benznidazole showed a significant reduction in all parameters of infection at all concentrations tested (Figure $2 \mathrm{~d}-\mathrm{f}$ ). The alterations in intracellular amastigote form of $T$. cruzi after treatment with ravenelin are represented in photomicrography images of Figure 2g.

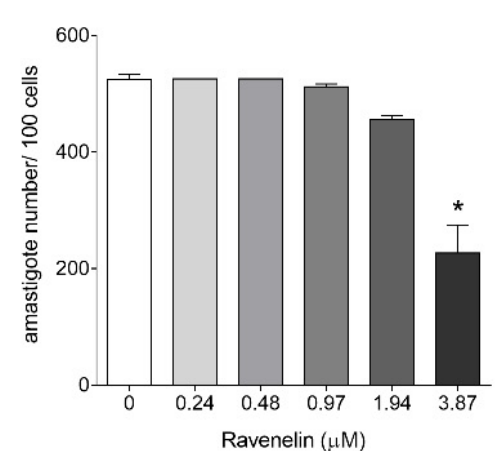

(a)

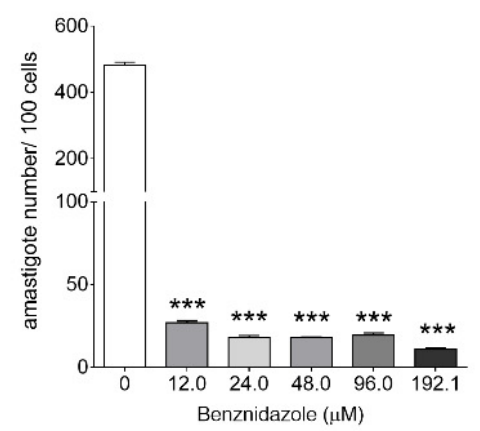

(d)

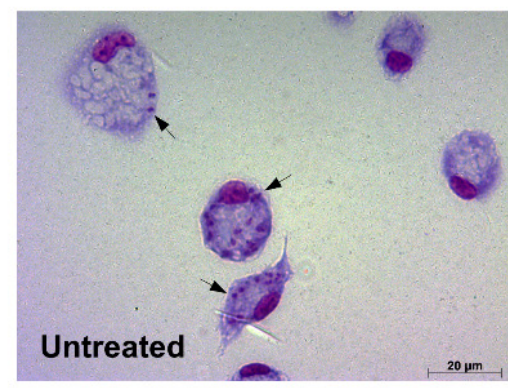

$20 \mathrm{\mu m}$

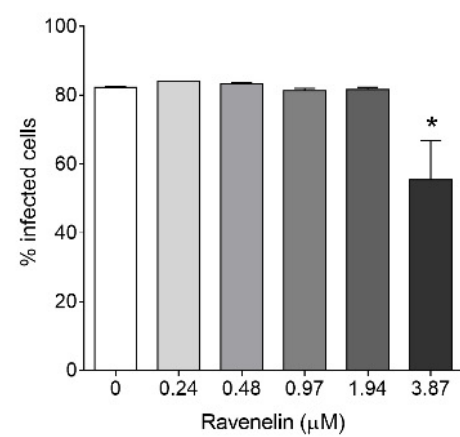

(b)

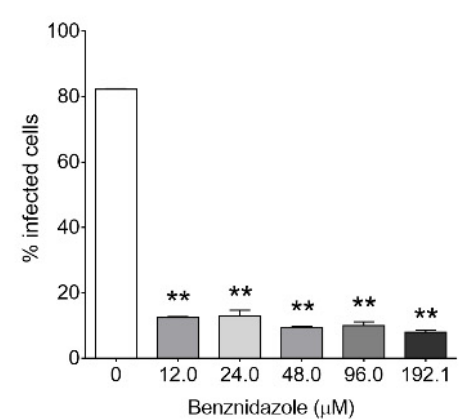

(e)

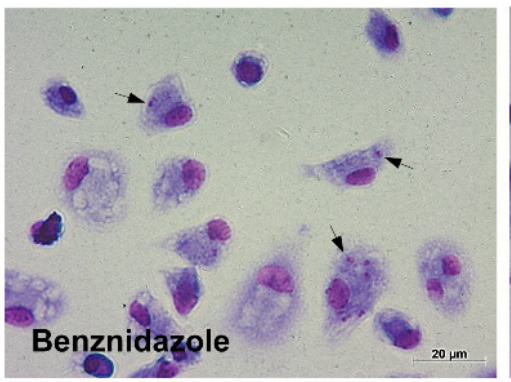

(g)

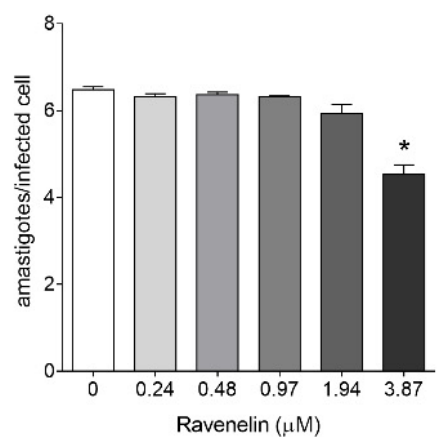

(c)

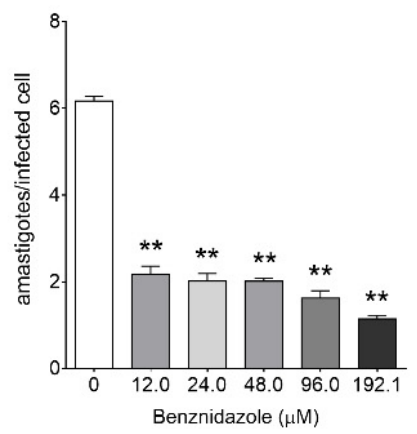

(f)

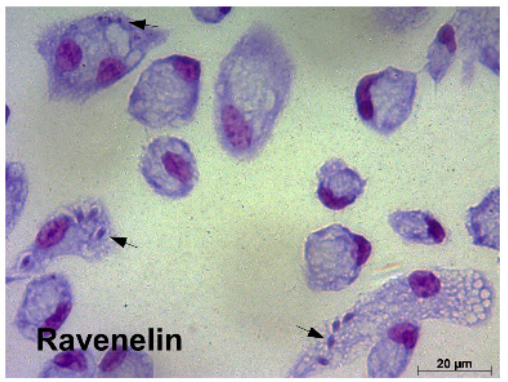

Figure 2. Infection parameters of BALB/c peritoneal macrophages infected with T. cruzi and treated for $24 \mathrm{~h}$ with ravenelin or benznidazole. (a-f) Parameters of infection and (g) light microscopy after ravenelin or benznidazole treatment at $3.87 \mu \mathrm{M}$ or $192.1 \mu \mathrm{M}$, respectively. Intracellular amastigotes inside macrophages (black arrows). Data represent mean \pm standard deviation of two independent experiments conducted in triplicate. ${ }^{*} p<0.05$, ${ }^{* *} p<0.01$ and ${ }^{* * *} p<0.001$, when compared to the untreated group by the Mann-Whitney test.

\subsection{Cytotoxicity and Selectivity Index of Ravenelin}

The cytotoxic effect and analysis of the selectivity index $\left(\mathrm{SI}=\mathrm{CC}_{50} / \mathrm{IC}_{50}\right)$ indicate whether a compound is selectively toxic to the parasite compared to other cells. In this sense, ravenelin was selective for P. falciparum $\left(\mathrm{CC}_{50}>50\right.$; $\left.\mathrm{SI}>15\right)$ in comparison with 
HepG2 cells (Table 3). Similarly, the cytotoxicity analysis of peritoneal macrophages treated with ravenelin showed a $C_{50}$ value of $185 \mu \mathrm{M}(47.7 \mu \mathrm{g} / \mathrm{mL})$ and a selectivity index of 21 (Table 3).

Table 3. Cytotoxicity in HepG2 cell and BALB/c peritoneal macrophages, and selectivity index of ravenelin.

\begin{tabular}{|c|c|c|c|c|}
\hline \multirow{2}{*}{ Compound } & HepG2 & \multirow{2}{*}{$S I^{a}$} & Peritoneal Macrophage & \multirow{2}{*}{$\mathrm{SI}^{\mathrm{b}}$} \\
\hline & $\mathrm{CC}_{50}(\mu \mathrm{M})$ & & $\mathrm{CC}_{50}(\mu \mathrm{M})$ & \\
\hline Ravenelin & $>50$ & $>15$ & $185 \pm 1$ & 21 \\
\hline Artesunate & $110 \pm 30$ & 13,000 & NA & NA \\
\hline Benznidazole & NA & ND & $666 \pm 1$ & 333 \\
\hline
\end{tabular}

Data represents mean \pm SD of at least two experiments realized in . $\mathrm{CC}_{50}$ : cytotoxic concentration for $50 \%$ of cells; SI ${ }^{\text {a }}$ : selectivity index in relation to inhibitory concentration for $50 \%$ of $P$. falciparum $3 \mathrm{D} 7 . \mathrm{SI}^{\mathrm{b}}$ : selectivity index in relation to inhibitory concentration for $50 \%$ of $T$. cruzi intracellular amastigote. NA, not applicable; ND, not determined.

\section{Discussion}

Ravenelin was isolated by chromatographic procedures and identified by 1D and 2D NMR, FTIR, and MS data. NMR data of ravenelin reported herein were compared with those published in the literature for the xanthone ravenelin [24,25].

In this study, ravenelin was tested for antibacterial activities against E. coli, P. aeruginosa, B. subtilis, S. Typhimurium, and S. aureus. In general, ravenelin exhibited pronounced antibacterial activity against the Gram-positive bacteria (B. subtilis and S. aureus) only. The tetraoxygenated xanthone derivatives isolated from immature fruits of Garcinia cowa also showed antibacterial activities against the Gram-positive strains, especially against $B$. subtilis (MIC value of $0.25-4 \mu \mathrm{g} / \mathrm{mL}$ ) [26]. In another study, $\alpha$-mangostin, the major xanthone derivative from Garcinia mangostana, was investigated for antimicrobial activity [27]. The natural product was a poor inhibitor of E. coli and P. aeruginosa $\left(\mathrm{IC}_{50}>200 \mu \mathrm{g} / \mathrm{mL}\right)$. However, the molecule showed inhibitory activity against both $B$. subtilis and $S$. aureus (MIC 1.6 and $3.2 \mu \mathrm{g} / \mathrm{mL}$ ) [27].

The investigation of the biological activities of secondary metabolites produced by associated fungi such as Talaromyces funiculosus and Diorygma hieroglyphicum led to the isolation of ravenelin, which exhibited an MIC value of $372 \mu \mathrm{M}$ against S. aureus [28]. These data, together with antibacterial data obtained by Padhi et al. (2019), which assessed the activity of ravenelin, suggest a possible affinity of this xanthone for Gram-positive bacteria.

There are few studies addressing the antiprotozoal activity of xanthones isolated from endophytic fungi. One of these studies demonstrated the antiplasmodial and trypanocidal activity for this chemical class. For instance, ascherxanthone A, isolated from the fungus Aschersonia sp., exhibited significant inhibitory activity against $P$. falciparum (K1 strains), with an $\mathrm{IC}_{50}$ value of $0.20 \mu \mathrm{g} / \mathrm{mL}$. Nonetheless, the compound showed noticeable cytotoxicity to Vero cells $\left(\mathrm{IC}_{50}=0.80 \mu \mathrm{g} / \mathrm{mL}\right)$ [29]. Phomoxanthones A and B, two xanthone dimers isolated from the endophytic fungus Phomopsis sp. BCC 1323, exhibited significant antiplasmodial activity against $P$. falciparum (K1 strain) with $\mathrm{IC}_{50}$ values of 0.11 and $0.33 \mu \mathrm{g} / \mathrm{mL}$, respectively, and a moderate cytotoxic effect on Vero cells ( $\mathrm{IC}_{50} 1.4$ and $1.8 \mu \mathrm{g} / \mathrm{mL}$, respectively) [30]. Similar results were observed with $\alpha$-mangostin, a low micromolar P. falciparum inhibitor $\left(\mathrm{IC}_{50}=2.2 \mu \mathrm{M}\right)$ with cytotoxic effects on MRC-5 cells in the same activity range $\left(\mathrm{IC}_{50}=7.5 \mu \mathrm{M}\right)$, thereby suggesting non-specific inhibition. These results agree with the data obtained in this study, which indicated that ravenelin is active for P. falciparum with inhibitory activity at the low micromolar range. However, ravenelin showed low cytotoxic activity on HepG2 cells, suggesting the natural compound has an acceptable selectivity index $(\mathrm{SI}>15)$ related to the known xanthone derivatives.

Moreover, ravenelin showed activity against both the epimatigote and the intracellular amastigote forms of T. cruzi. Xanthone derivatives with trypanocidal potential have also been reported. For example, Dua et al. [31] isolated four xanthones from the roots 
of Andrographis paniculata and tested the compounds against trypomastigote forms of T. brucei brucei, intracellular amastigotes of T. cruzi, and Leishmania infantum. The compound 1,2-dihydroxy-6,8-dimethoxy-xanthone showed promising activity against $T . b$. brucei and L. infantum with $\mathrm{IC}_{50}$ of $4.6 \mu \mathrm{g} / \mathrm{mL}$ and $8 \mu \mathrm{g} / \mathrm{mL}$, respectively [31]. Similarly, Al-Massarani et al. [27] demonstrated that $\alpha$-mangostin was active against intracellular amastigotes of L. infantum, and trypomastigotes of T. brucei, and T. cruzi, with $\mathrm{IC}_{50}$ values in the low micromolar range $\left(\mathrm{IC}_{50} \mathrm{~s}\right.$ between 8.0 and $\left.9.0 \mu \mathrm{M}\right)$. In addition, Dua et al. [31] indicated that 1,2-dihydroxy-6,8-dimethoxy-xanthone showed $\mathrm{CC}_{50}$ values $>32 \mu \mathrm{g} / \mathrm{mL}$ against mammalian cells (MRC-5, human lung fibroblast), as well as $\alpha$-mangostin, showed cytotoxicity on MRC-5 cells $\left(\mathrm{CC}_{50}=7.5 \mu \mathrm{M}\right)[5,27]$. Our study indicated that ravenelin showed cytotoxic effects on peritoneal macrophages at a concentration 3.6-fold lower than benznidazole (the reference drug). However, in comparison with trypanocidal activity, ravenelin showed substantial selectivity indexes of 37 and 21 against the epimastigote and intracellular amastigote forms of T. cruzi, respectively. Selectivity indexes greater than 10 indicate that biological efficacy is not due to in vitro cytotoxicity [32].

\section{Materials and Methods}

\subsection{Plant Material}

Phanera splendens (Kunth) Vaz (Leguminosae) was collected in the city of Belém, Pará State, Brazil, in December 2016, and a voucher specimen (number IAN 177.179) was deposited at the Herbarium of the Brazilian Agricultural Research Corporation (EMBRAPA).

\subsection{E. rostratum Isolation}

The E. rostratum fungus was isolated from in natura healthy tissues of $P$. splendens (Kunth) Vaz (Leguminosae) through a sequence of immersions of small pieces of plant material in hexane, $4 \%$ aqueous solution of sodium hypochlorite, $70 \%$ ethanol, and sterile water. The plant material was inoculated into a $9 \mathrm{~cm}$ Petri dish containing a Potato Dextrose Agar (PDA) culture medium (HiMedia, Mumbai, India) and incubated for seven days at $25^{\circ} \mathrm{C}$ for colony growth, which was purified by successive sampling. The E. rostratum fungus was identified by DNA sequencing at the Institute of Biological Sciences, Federal University of Pará (UFPA).

\subsection{Culture of E. Rostratum in Rice and Compound Isolation}

The fungus was cultivated in forty-five Erlenmeyer flasks $(500 \mathrm{~mL})$ containing $90 \mathrm{~g}$ of rice and $75 \mathrm{~mL}$ of distilled water per flask. Three flasks (rice only) were used as control. Small pieces of PDA from the Petri dish containing mycelium of E. rostratum were transferred under sterile conditions to forty-two Erlenmeyer flasks previously autoclaved for $45 \mathrm{~min}$ at $121{ }^{\circ} \mathrm{C}$, and stored for twenty-eight days at $25^{\circ} \mathrm{C}$ for colony growth. The biomass obtained was macerated with ethyl acetate ( $2 \mathrm{~L}$, three times). After simple filtration, the solution was concentrated in a rotary evaporator, and the ethyl acetate biomass extracts $(22.5 \mathrm{~g})$ were obtained. A part of the ethyl acetate extract $(3.0 \mathrm{~g})$ was fractionated on a chromatography column using silica gel SiliaSphere ${ }^{\mathrm{TM}}$ (Silicycle, Québec, QC, Canada, 60-200 mesh) as stationary phase and hexane, ethyl acetate, and methanol as mobile phase in the polarity gradient, and A1 to A6 fractions were given (A1: Hexene; A2: Hexene/Ethyl Acetate 8:2; A3: Hexene/Ethyl Acetate 1:1; A4: Hexene/Ethyl Acetate 2:8; A5: Ethyl Acetate; and A6: Methanol, 1L each). Afterwards, the A1 to A6 solution fractions were concentrated in the rotatory evaporator (Quimis, Diadema, SP, Brazil) and were analyzed by thin-layer chromatography (TLC) on silica gel and mobile phase hexane/ethyl acetate 6:4. The compound ravenelin ( $25 \mathrm{mg}$ ) was isolated from fraction A3 by high-performance liquid chromatography HPLC-PAD in preparative mode using a Waters 1525 Binary HPLC Pump (Waters, Milford, MA, USA) equipped with Waters 2998 photodiode array detector and Sunfire ${ }^{\mathrm{TM}}$ prep C18 column $(5 \mu \mathrm{m}, 19 \mathrm{~mm} \times 150 \mathrm{~mm})$. Chromatographic separation occurred with $500 \mu \mathrm{L}$ of the injected volume of the sample with elution of a gradient of 
$\mathrm{H}_{2} \mathrm{O} / \mathrm{MeOH}(90-100 \%)$ for $16 \mathrm{~min}$, with a flow rate of $9.0 \mathrm{~mL} / \mathrm{min}$. The wavelength was scanned in the range of $210-600 \mathrm{~nm}$. The wavelength monitored was $254 \mathrm{~nm}$.

\subsection{NMR and MS Analysis}

The mass spectrum was obtained in negative ion mode using an Acquity tandem quadrupole detector (TQD) (Waters, Milford, MA, USA) mass spectrometer equipped with an electrospray ionization source (ESI). The 1D and 2D NMR spectra were recorded on a Bruker Ascend 400 (Bruker, Fällanden, Switzerland). Ravenelin was solubilized in acetone$\mathrm{d}_{6}$ to record NMR spectra. The chemical shifts are given in delta $(\delta)$ values and the coupling constants $(J)$ in Hertz $(\mathrm{Hz})$, and the solvent signal (acetone- $\mathrm{d}_{6}$ ) was used as reference. The IR spectrum was obtained on an Agilent Cary 630 FTIR (Agilent Technologies, Santa Clara, CA, USA).

\subsection{Parasites}

The P. falciparum 3D7 strain was kept in RPMI 1640 medium with $25 \mathrm{mM} \mathrm{NaHCO}_{3}$, $25 \mathrm{mM}$ HEPES (pH 7.4), $11 \mathrm{mM}$ D-glucose, $3.67 \mathrm{mM}$ hypoxanthine, and $50 \mathrm{mg} / \mathrm{mL}$ gentamicin, supplemented with $0.5 \%$ of the lipid-rich bovine serum albumin AlbuMAX II and incubated at $37^{\circ} \mathrm{C}$. The culture medium was changed daily. Parasitaemia was maintained below $10 \%$, with $2.5 \%$ hematocrit in human O+ erythrocytes [33]. The Y strain of T.cruzi was isolated from a patient in the acute phase of Chagas disease [34], and the epimastigote forms were cultured at $28^{\circ} \mathrm{C}$ in liver infusion tryptose (LIT) medium [35]. The cultures used had a maximum of six in vitro passages.

\subsection{Animals}

Healthy 4-6-year-old female BALB/c mice, purchased from the Institute of Science and Technology in Biomodels of Oswaldo Cruz Foundation, were used. Animal procedures were performed in accordance with the National Council for Control of Animal Experimentation (Conselho Nacional de Controle de Experimentação Animal-CONCEA) and approved by the local Ethics Committee on Animal Care and Utilization (CEUA-IOC L-018/2018).

\subsection{Cell Culture}

Hepatocarcinoma cells (HepG2) were cultivated in RPMI 1640 (Sigma, St. Louis, MI, USA) medium, and the African green monkey kidney VERO cell line was cultivated in Dulbecco's modified eagle medium (DMEM) (Sigma, St. Louis, MI, USA). Cells were cultivated at $37{ }^{\circ} \mathrm{C}$ and $5 \% \mathrm{CO}_{2}$, and the supplemented medium was changed every two days. Peritoneal macrophages were obtained from BALB/c mice elicited with $3 \mathrm{~mL} \mathrm{3 \%}$ thioglycolate for $72 \mathrm{~h}$ and kept in RPMI 1640 (Sigma, St. Louis, MI, USA) [36]. Both cells were supplemented with $10 \%$ fetal bovine serum, penicillin $(100 \mathrm{U} / \mathrm{mL})$, and streptomycin $(100 \mu \mathrm{g} / \mathrm{mL})$ at $37^{\circ} \mathrm{C}$ and $5 \% \mathrm{CO}_{2}$.

\subsection{Antimicrobial Assay}

The antimicrobial susceptibility was carried out by microbroth dilution assay [37]. Tests were performed on 96-well plates with $100 \mu \mathrm{L}$ of Mueller Hinton Broth (MHB) (HiMedia, Mumbai, India), $100 \mu \mathrm{L}$ of test compound, and $5 \mu \mathrm{L}$ of test bacteria at 1.0 $\times 10^{4} \mathrm{CUF} / \mathrm{mL}$, followed by incubation at $37^{\circ} \mathrm{C}(24 \mathrm{~h})$. The ravenelin obtained from the fungal culture was dissolved (initially $1 \mathrm{mg}$ ) in $100 \mu \mathrm{L}$ of dimethyl sulfoxide (DMSO) and $900 \mu \mathrm{L}$ of brain heart infusion (BHI) broth given $1 \mathrm{mg} / \mathrm{mL}(3876 \mu \mathrm{M})$ stock solution. The stock solution was diluted from $3.876 \mu \mathrm{M}$ to $0.95 \mu \mathrm{M}$ for testing. Escherichia coli (ATCC 25922), Pseudomonas aeruginosa (ATCC 27853), Salmonella typhimurium (ATCC 14028), Staphylococcus aureus (ATCC 25923), and Bacillus subtilis (ATCC 6633) were provided by the Evandro Chagas Institute, Belém, Pará State, Brazil. Bioactivity was registered as red coloration absence in the wells after addition of $10 \mu \mathrm{L}$ 2,3,5-triphenyltetrazolium chloride. The microorganisms were then sub-cultured on MHB plates. The activities of test 
compounds were classified as bacteriostatic or bactericidal according to the behavior of the microorganisms in these sub-cultures. Amoxicillin and terramycin were used as positive controls and the MHB culture medium was used as a negative control. The test was made in triplicate.

\subsection{Antiplasmodial Assay}

Parasites were synchronized to enrich the ring-stage parasites through sterile 5\% $(\mathrm{m} / \mathrm{v})$ D-sorbitol treatment incubated at $37{ }^{\circ} \mathrm{C}$ for $10 \mathrm{~min}$ [38], followed by centrifugation at $600 \times g$ for $5 \mathrm{~min}$. After resuspension of the centrifuged parasites, parasitemia was determined by microscope analysis of thin blood smears stained with Giemsa 10\% solution after methanol fixation. Parasitemia was calculated from 1000 red blood cells (RBCs) with dilution of cultures of $0.5 \%$ parasitemia and $2 \%$ hematocrit by adding the appropriate volumes of erythrocytes and medium. A total of $180 \mu \mathrm{L}$ of parasite aliquots were distributed into 96-well plates, previously prepared with $20 \mu \mathrm{L}$ aliquots of a ten-fold concentrated compound. The controls were distributed in wells, with the negative and positive controls corresponding to non-parasitized erythrocytes, and parasite cultures in the absence of compounds were set in parallel. DMSO with a concentration below $0.05 \%$ $(v / v)$ was used to assist in the solubilization of the compounds. Plates were organized in a humidified incubator with a gas mixture of $90 \% \mathrm{~N}_{2}, 5 \% \mathrm{O}_{2}$, and $5 \% \mathrm{CO}_{2}$ at $37{ }^{\circ} \mathrm{C}$ for $72 \mathrm{~h}$. After incubation, the culture medium was removed, followed by re-suspending in $100 \mu \mathrm{L}$ phosphate-buffered saline (PBS) buffer $\left(116 \mathrm{mM} \mathrm{NaCl}, 10 \mathrm{mM} \mathrm{Na} 2 \mathrm{HPO}_{4}, 3 \mathrm{mM}\right.$ $\left.\mathrm{KH}_{2} \mathrm{PO}_{4}\right)$ and lysing with $100 \mu \mathrm{L}$ lysis buffer $(20 \mathrm{mM}$ Tris base, $5 \mathrm{mM}$ EDTA, $0.0008 \%$ $(v / v)$ Triton $\mathrm{X}-100,0.008 \%(\mathrm{~m} / \mathrm{v})$ saponin, $\mathrm{pH} 8.0)$ containing $0.002 \%(v / v)$ SYBR Green I. Further incubation was performed at room temperature for $30 \mathrm{~min}$, followed by determination of the parasitic density by fluorescence using a SpectraMAX Gemini EM plate reader (Molecular Devices Corp., Sunnyvale, CA, USA) (excitation at $485 \mathrm{~nm}$, emission at $535 \mathrm{~nm}$ ) [39]. Half maximal inhibitory concentration $\left(\mathrm{IC}_{50}{ }^{\mathrm{Pf}}\right)$ was determined by non-linear regression analysis of the resulting concentration-response curve using the software Origin 2016 (OriginLab Corporation).

\subsection{Antitrypanosomal Activity Assay}

The epimastigote forms of T. cruzi $\left(2 \times 10^{6}\right.$ parasites $\left./ \mathrm{mL}\right)$ from a 3-5-day-old culture were incubated for $24 \mathrm{~h}$ in 96-well plates in the presence of different concentrations of ravenelin $(3.78-1000 \mu \mathrm{M})$ at least in triplicate, with a final volume of $100 \mu \mathrm{L}$ per well. Wells without parasites were used as blank, and wells containing only parasites were used as control. The viability of parasites was evaluated after treatment by counting the total number of live epimastigotes, taking into account the flagellar motility, using a Neubauer chamber and light microscope. This count was compared with the score of nontreated epimastigote growth. This experiment was carried out in triplicate. The results are expressed as parasite growth inhibitory concentration $\left(\mathrm{IC}_{50}\right)$. Benznidazole $(3.0-384.3 \mu \mathrm{M})$, was used as reference drug. Activity against intracellular amastigotes was performed with peritoneal macrophages cultured in 24 -well plates $\left(5 \times 10^{5}\right.$ cells/well) with coverslips and infected with trypomastigotes forms of T. cruzi using a ratio of 10:1 parasite/cell. After $6 \mathrm{~h}$, the cells were washed three times with PBS to remove free parasites. The infected cells were treated with ravenelin $(0.242-3.87 \mu \mathrm{M})$ and benznidazole $(24.0-384.3 \mu \mathrm{M})$ at least in triplicate for $24 \mathrm{~h}$. Coverslips with the infected and treated cells were fixed with Bouin solution stained with Giemsa solution and examined under light microscopy. The intracellular amastigote number of one hundred cells was normalized and used to calculate the $\mathrm{IC}_{50}[40]$.

\subsection{Cytotoxicity Test and Selectivity Index}

Hepatocarcinoma cell and peritoneal macrophages were cultured in 96-well plates $\left(5 \times 10^{5}\right.$ cells $\left./ \mathrm{mL}\right)$ with different concentrations of ravenelin $(7.5-242.0 \mu \mathrm{M})$ and benznidazole $(24.0-768.5 \mu \mathrm{M})$ at least in triplicate up to a final volume of $100 \mu \mathrm{L}$ per well at $37^{\circ} \mathrm{C}$ 
and $5 \% \mathrm{CO}_{2}$. Wells without cells were used as blanks, and wells with cells and DMSO $1 \%$ were only used as controls. After $24 \mathrm{~h}$, cell viability was evaluated by modified colorimetric method with tetrazolium-dye 3-(4,5-dimethylthiazol-2-yl)-2,5-diphenyltetrazolium bromide (MTT) [41]. The results were used to calculate the $50 \%$ cell cytotoxicity $\left(\mathrm{CC}_{50}\right)$. The selectivity index (SI) was obtained from the ratio of peritoneal macrophages $\mathrm{CC}_{50}$ and $\mathrm{IC}_{50}$ [42].

\subsection{Statistical Analysis}

The $\mathrm{IC}_{50}$ and $\mathrm{CC}_{50}$ were obtained from a nonlinear regression fit curve of concentration in log versus normalized response. The values were expressed as mean \pm S.D. Analyses were performed using the software GraphPad Prism (Version 6.01, GraphPad Software Inc., La Jolla, San Diego, CA, USA), and differences were considered significant when $p<0.05$.

\section{Conclusions}

The present work reported the isolation and structural characterization of ravenelin, a secondary metabolite from E. rostratum. Our findings indicated that the natural product is endowed with both antibacterial (B. subtilis) and antiparasitic (P. falciparum and T. cruzi) activities, with considerable selectivity indexes. These results suggest that ravenelin is an attractive candidate for hit-to-lead development, especially for Chagas Disease, a serious public health problem in Latin America.

Supplementary Materials: The following are available online, Figure S1-S7: NMR, IR, and MS spectra of the active compound are available online.

Author Contributions: J.R.S.P., J.V.S.-S., R.V.C.G., P.S.B.M., and A.M.d.R.M. designed the study, wrote the paper, and participated in the research; J.M.C., H.R.B., J.R.S.P., J.M.C., and P.S.B.M. participated in the phytochemical characterization of ravenelin; J.M.P.F., A.C.C.A., L.A.W., and G.E.d.S. performed the in vitro studies; F.A.-S., K.d.S.C., A.M.d.R.M., and P.S.B.M. contributed to the analysis of the data. All authors discussed the data obtained and collaborated in drafting the manuscript. All authors have read and agreed to the published version of the manuscript.

Funding: This research was funded by the Fundação Amazônia de Amparo a Estudos e Pesquisa do Pará (FAPESPA), Conselho Nacional de Desenvolvimento Científico e Tecnológico (CNPq, grant 405330/2016-2), Coordenação de Aperfeiçoamento de Pessoal de Ensino Superior (CAPES, Finance Code 001, grant 88887.368507/2019-00), Fundação de Amparo à Pesquisa do Estado do Rio de Janeiro (FAPERJ, grant E-26/210.344/2019, and E-26/201.765/2019), and Fundação de Amparo à Pesquisa do Estado de São Paulo (FAPESP, CEPID grant 2013/07600-3 and 2020/12904-5). Fernando Almeida-Souza is a postdoctoral researcher fellow of CAPES grant number 88887.363006/2019-00.

Institutional Review Board Statement: The experiments with animals were conducted in accordance with the guidelines for experi-mental procedures of the Conselho Nacional de Controle de Experimentação Animal (the Na-tional Council for the Control of Animal Experimentation) (CONCEA) and approved by the Comissão de Ética no Uso de Animais (the Animal Research Ethics Committee) of the Instituto Oswaldo Cruz (CEUA-IOC/FIOCRUZ), License nº L018/2018.

Informed Consent Statement: Not applicable.

Data Availability Statement: The data presented in this study are available in Supplementary Material.

Acknowledgments: The authors thank all the collaborators of the UFPA, PROPESP/UFPA, IOC/ FIOCRUZ, USP São Carlos and UEMA for technical support.

Conflicts of Interest: The authors declare no conflict of interest.

Sample Availability: Samples of the compounds ravenelin are available from the authors.

\section{References}

1. Camele, I.; Elshafie, H.S.; Caputo, L.; Sakr, S.H.; De Feo, V. Bacillus mojavensis: Biofilm formation and biochemical investigation of its bioactive metabolites. J. Biol. Res. 2019, 92, 8296.

2. Gaynes, R. The Discovery of Penicillin-New Insights after More Than 75 Years of Clinical Use. Emerg. Infect. Dis. 2017, 23, 849-853. 
3. Newman, J.D.; Cragg, G.M. Natural Products as Sources of New Drugs from 1981 to 2014. J. Nat. Prod. 2016, 79, 629-661.

4. Massand, M.; Jose, P.A.; Menghani, E.; Jebakumar, S.R.D. Continuing hunt for endophytic actinomycetes as a source of novel biologically active metabolites. World J. Microbiol. Biotechnol. 2015, 12, 1863-1875.

5. Gutierrez, R.M.P.; Gonzalez, A.M.N.; Ramirez, A.M. Compounds Derived from Endophytes: A Review of Phytochemistry and Pharmacology. Curr. Med. Chem. 2012, 19, 2992-3030.

6. Roca, I.; Akova, M.; Baquero, F.; Carlet, J.; Cavaleri, M.; Coenen, S.; Cohen, J.; Findlay, D.; Gyssens, I.; Heure, O.E.; et al. The global threat of antimicrobial resistance: Science for intervention. New Microbes New Infect. 2015, 6, $22-29$.

7. Capela, R.; Moreira, R.; Lopes, F. An Overview of Drug Resistance in Protozoal Diseases. Int. J. Mol. Sci. $2019,20,5748$.

8. Wang, C.; Tang, S.; Cao, S. Antimicrobial compounds from marine fungi. Phytochem. Rev. 2021, $20,85-117$.

9. Sappapan, R.; Sommit, D.; Ngamrojanavanich, N.; Pengpreecha, S.; Wiyakrutta, S.; Sriubolmas, N.; Pudhom, K. 11-Hydroxymonocerin from the Plant Endophytic Fungus Exserohilum rostratum. J. Nat. Prod. 2008, 7, 1657-1659.

10. Peres, V.; Nagem, T.J.; Oliveira, F.F. Tetraoxygenated naturally occurring xanthones. Phytochemistry 2000, 55, 683-710.

11. Song, X.Q.; Zhang, X.; Han, Q.J.; Li, X.B.; Li, G.; Li, R.J.; Jiao, Y.; Zhou, J.C.; Lou, H.X. Xanthone derivatives from Aspergillus sydowii, an endophytic fungus from the liverwort Scapania ciliat S. Lac and their immunosuppressive activities. Phytochem. Lett. 2013, 6, 318-321.

12. Mandal, S.; Das, P.C.; Joshi, P.C. Naturally occurring xanthones from terrestrial flora. J. Indian Chem. Soc. 1992, 69, 611-636.

13. Zhang, S.J.; Ding, Z.S.; Jiang, F.S.; Ge, Q.F.; Guo, D.W.; Lid, H.B.; Hu, W.X. Synthesis, anticancer evaluation and docking study of vadimezan derivatives with carboxyl substitution. MedChemComm 2014, 5, 512-520.

14. Pytka, K.; Żmudzka, E.; Lustyk, K.; Rapacz, A.; Olczyk, A.; Gałuszka, A.; Waszkielewicz, A.; Marona, H.; Sapa, J.; Barbara, F. The antidepressant- and anxiolytic-like activities of new xanthone derivative with piperazine moiety in behavioral tests in mice. Indian J. Pharmacol. 2016, 48, 286-291.

15. Ghosal, S.; Chaudhuri, R.K. Chemical constituents of gentianaceae XVI: Antitubercular activity of xanthones of Canscora decussata Schult. J. Pharm. Sci. 1975, 64, 888-889.

16. Araújo, J.; Fernandes, C.; Pinto, M.; Tiritan, M.E. Chiral Derivatives of Xanthones with Antimicrobial Activity. Molecules 2019, 24, 314.

17. Shan, T.; Ma, Q.; Guo, K.; Liu, J.; Li, W.; Wang, F.; Wu, E. Xanthones from mangosteen extracts as natural chemopreventive agents: Potential anticancer drugs. Curr. Mol. Med. 2011, 11, 666-677.

18. Kang, H.H.; Zhang, H.B.; Zhong, M.J.; Ma, L.Y.; Liu, D.S.; Liu, W.Z.; Ren, H. Potential Antiviral Xanthones from a Coastal Saline Soil Fungus Aspergillus iizukae. Mar. Drugs 2018, 16, 449.

19. Zhao, Y.; Liu, J.P.; Lu, D.; Li, P.Y.; Zhang, L.X. A new antioxidant xanthone from the pericarp of Garcinia mangostana Linn. Nat. Prod. Res. 2010, 24, 1664-1670.

20. Feng, Z.; Lu, X.; Gan, L.; Zhang, Q.; Lin, L. Xanthones, A Promising Anti-Inflammatory Scaffold: Structure, Activity, and Drug Likeness Analysis. Molecules 2020, 25, 598.

21. Mbwambo, Z.H.; Kapingu, M.C.; Moshi, M.J.; Machumi, F.; Apers, S.; Cos, P.; Ferreira, D.; Marais, J.P.; Vanden Berghe, D.; Maes, L.; et al. Antiparasitic activity of some xanthones and biflavonoids from the root bark of Garcinia livingstonei. J. Nat. Prod. 2006, 69, 369-372.

22. Cechinel Filho, V. Chemical composition and biological potential of plants from the genus Bauhinia. Phytother. Res. 2009, 23, 1347-1354.

23. Pinheiro, E.A.A.; Borges, F.C.; Pina, J.R.S.; Ferreira, L.R.S.; Cordeiro, J.S.; Carvalho, J.M.; Feitosa, A.O.; Campos, F.R.; Barison, A.; Souza, A.D.L.; et al. Annularins I and J: New metabolites isolated from endophytic fungus Exserohilum rostratum. J. Braz. Chem. Soc. 2016, 27, 1432-1436.

24. Raistrick, H.; Robinson, R.; White, D.E. Studies in the biochemistry of micro-organisms: Ravenelin (3-methyl-1:4:8-trihydroxyxanthone), a new metabolic product of Helminthosporium Ravenelii Curtis and of H. turcicum Passerini. Biochem. J. 1936, 30, $1303-1314$.

25. Westerman, P.W.; Gunasekera, S.P.; Uvais, M.; Sultanbawa, S.; Kazlauskas, R. Carbon-13 N.M.R. study of naturally occurring xanthones. Org. Magn. Reson. 1977, 9, 631-636.

26. Auranwiwat, C.; Trisuwan, K.; Saiai, A.; Pyne, S.G.; Ritthiwigrom, T. Antibacterial tetraoxygenated xanthones from the immature fruits of Garcinia cowa. Fitoterapias 2014, 98, 179-183.

27. Al-Massarani, S.M.; El-Gamal, A.A.; Al-Musayeib, N.M.; Mothana, R.A.; Basudan, O.A.; Al-Rehaily, A.J.; Farag, M.; Assaf, M.H.; El Tahir, K.H.; Maes, L. Phytochemical, antimicrobial and antiprotozoal evaluation of Garcinia mangostana pericarp and $\alpha-$ mangostin, its major xanthone derivative. Molecules 2013, 18, 10599-10608.

28. Padhi, S.; Masi, M.; Cimmino, A.; Tuzi, A.; Jena, A.; Tayung, K.; Evidente, A. Funiculosone, a substituted dihydroxanthene1,9-dione with of its analogues proced by na endolichenic fungus Talaromyces funiculosus and their antimicrobial activity. Phytochemistry 2019, 157, 175-183.

29. Isaka, M.; Palasarn, S.; Kocharin, K.; Saenboonrueng, J. A Cytotoxic Xanthone Dimer from the Entomopathogenic Fungus Aschersonia sp. BCC 8401. J. Nat. Prod. 2005, 68, 945-946.

30. Isaka, M.; Jaturapat, A.; Rukseree, K.; Danwisetkanjana, K.; Tanticharoen, M.; Thebtaranonth, Y. Phomoxanthones A and B, novel xanthone dimers from the endophytic fungus Phomopsis species. J. Nat. Prod. 2001, 64, 1015-1018.

31. Dua, V.K.; Verma, G.; Dash, A.P. In Vitro Antiprotozoal Activity of Some Xanthones Isolated from the Roots of Andrographis paniculata. Phytother. Res. 2009, 23, 126-128. 
32. Weniger, B.; Robledo, S.; Arango, G.J.; Deharo, E.; Aragón, R.; Muñoz, V.; Callapa, J.; Lobstein, A.; Anton, R. Antiprotozoal activities of Colombian plants. J. Ethnopharmacol. 2001, 78, 193-200.

33. Trager, W.; Jensen, J.B. Human malaria parasites in continuous culture. Science 1976, 193, 673-675.

34. Pereira da Silva, L.H.; Nussenzweig, V. Sobre uma cepa de Trypanosoma cruzi altamente virulenta para camundongos brancos. Folia Clin. Biol. 1953, 20, 191-208.

35. Castellani, O.; Ribeiro, L.V.; Fernandes, J.F. Differentiation of Trypanosoma cruzi in culture. J. Protozool. 1967, 14, $447-451$.

36. Teles, A.M.; Silva, J.V.S.; Fernandes, J.M.P.; Abreu-Silva, A.L.; Calabrese, K.S.; Mendes-Filho, N.E.; Mouchrek, A.N.; Almeida-Souza, F. GC-MS Characterization of Antibacterial, Antioxidant, and Antitrypanosomal Activity of Syzygium aromaticum Essential Oil and Eugenol. Evid. Based Complementary Altern. Med. 2021, 2021, 6663255.

37. CLSI. Performance Standards for Antimicrobial Disk Susceptibility Tests, 8th ed.; National Committee for Clinical Laboratory Standards: Wayne, PA, USA, 2017.

38. Lambros, C.; Vanderberg, J.P. Synchronization of Plasmodium falciparum erythrocytic stages in culture. J. Parasitol. 1979, 65, 418-420.

39. Vossen, M.G.; Pferschy, S.; Chiba, P.; Noedl, H. The SYBR Green I malaria drug sensitivity assay: Performance in low parasitemia samples. Am. J. Trop. Med. Hyg. 2010, 82, 398-401.

40. Teles, A.M.; Silva, J.V.S.; Fernandes, J.M.P.; Calabrese, K.S.; Abreu-Silva, A.L.; Marinho, S.C.; Mouchrek, A.N.; Mouchrek-Filho, V.E.; Almeida-Souza, F. Aniba rosaeodora (Var. amazonica Ducke) Essential Oil: Chemical Composition, Antibacterial, Antioxidant and Antitrypanosomal Activity. Antibiotics 2021, 10, 24.

41. Mosmann, T. Rapid colorimetric assay for cellular growth and survival: Application to proliferation and cytotoxicity assays. J. Immunol. Methods 1983, 65, 55-63.

42. Almeida-Souza, F.; Silva, V.D.; Silva, G.X.; Taniwaki, N.N.; Hardoim, D.J.; Buarque, C.D.; Abreu-Silva, A.L.; Calabrese, K.S. 1,4-Disubstituted-1,2,3-Triazole Compounds Induce Ultrastructural Alterations in Leishmania amazonensis Promastigote: An in Vitro Antileishmanial and in Silico Pharmacokinetic Study. Int. J. Mol. Sci. 2020, 21, 6839. 